\title{
Evolutionary Origin of Politics and Political Evolution: Neuropolitics
}

\author{
Dingyu Chung \\ Utica, Michigan, USA \\ Email: dy_chung@yahoo.com
}

How to cite this paper: Chung, D.Y. (2018) Evolutionary Origin of Politics and Political Evolution: Neuropolitics. Journal of Behavioral and Brain Science, 8, 538-561. https://doi.org/10.4236/jbbs.2018.810033

Received: August 30, 2018

Accepted: October 12, 2018

Published: October 15, 2018

Copyright $\odot 2018$ by author and Scientific Research Publishing Inc. This work is licensed under the Creative Commons Attribution International License (CC BY 4.0).

http://creativecommons.org/licenses/by/4.0/

\begin{abstract}
The paper proposes that the evolutionary origin of politics is based on imaginary prosocial societies for large-scale cooperation at the beginning of civilization established by large-scale civilized social groups. According to Dunbar, the size of the human brain is adapted to the manageable group size of about 150 people (Dunbar's Number). A manageable large-scale civilized social group much more than 150 people could not exist sustainably. To enhance group survival chance under such existential group-size pressure, large-scale civilized social groups invented politics for large-scale cooperation based on imaginary prosocial societies which founded prosocial religions of ancestor worship and high gods to enforce prosociality. (In modern times, imaginary prosocial societies founded secular nationalisms with elaborate rituals, monuments, and devotions to enforce prosociality.) This imaginary prosocial society became the foundation for a large-scale social group to establish a civilized social order for large-scale cooperation. Therefore, politics is defined as a civilized social order for large-group cooperation based on a shared imaginary prosocial society to enhance group survival chance under existential group-size pressure. Under politics with civilized social order, all types of large-scale cooperation became possible. In this paper, neuropolitics as the combination of neuroscience and political science is based on the political brain derived from the social brain through imagination and rationality. It explains the evolutionary origin of politics and the political evolution. The political imagination for imaginary prosocial society is derived from theory of mind that generates an imaginary prosocial society to have its own mind in its own imaginary world. The political rationality is derived from the rational brain that generates subjective rationality to defend a political view and objective rationality to create a new political view dialectically.
\end{abstract}

\section{Keywords}

Neuropolitics, Evolutionary Origin of Politics, Political Evolution, Neuroscience, 
Politics, Political Brain

\section{Introduction}

Politics derived from the Greek word "Polis" that means the city state is the activities of the city state. The city state involves a large-scale civilized social group, so politics is the activities of a large-scale civilized social group. The pre-civilized social group was a small-scale pre-civilized hunter-gatherer social group, so according to the original meaning of politics, a small-scale pre-civilized hunter-gatherer social group which was not a city state did not have politics. This paper proposes the evolutionary origin of politics as the activities of a large-scale civilized social group. In this paper, politics is explained in terms of neuropolitics [1] as the combination of neuroscience and political science. The evolutionary origin of politics relates to the evolutionary origin of prosocial religions by Norenzayan et al. [2] [3].

Norenzayan proposes that the evolutionary origin of prosocial religions resolves two puzzles in human psychology and cultural history: 1) the rise of large-scale cooperation among strangers and, simultaneously, 2) the spread of prosocial religions to promote social cooperation in the last $10-12$ millennia [2]. Norenzayan argues that these two developments were importantly linked and mutually energizing, even though the original religions derived from theory of mind were not adaptive to large-scale cooperation. The prosocial religions such as the prosocial religions with Big Gods were linked to the rise of large-scale cooperation. Norenzayan shows various historical evidences to prove the link between large-scale cooperation and prosocial religions. The activities of prosocial religions increased with the increasing sizes of large-scale social groups and intergroup competitions. The extreme examples of prosocial religions are prosocial religions with Big Gods that are characterized by the high intensity of supernatural punishment and interventionism culturally prevalent in particular place and time. Norenzayan hypothesizes that any cultural traits, religious or non-religious, that directly or indirectly promote in-group solidarity in increasingly expanding and competing groups, are more likely to persist through time and space, so prosocial religions are not a necessary, perhaps not even a sufficient cause of large-scale cooperation [2] [4].

What is the mechanism which has a necessary and sufficient cause for large-scale cooperation? The paper proposes that the mechanism that has a necessary and sufficient cause for large-scale cooperation is politics based on an imaginary prosocial society. According to Dunbar, the size of the human brain is adapted to the manageable group size of about 150 people (Dunbar's Number) [5]. A civilized social group had much more people than 150. Under such existential group-size pressure, a manageable large-scale civilized social group much more than 150 people could not exist sustainably. To enhance group survival 
chance under such existential group-size pressure, large-scale civilized social groups invented politics based on imaginary prosocial societies which founded prosocial religions of ancestor worship and high gods to enforce prosociality. (In modern times, imaginary prosocial societies founded secular nationalisms with elaborate rituals, monuments, and devotions to enforce prosociality.) Nationalism is based on an imaginary prosocial society. This imaginary prosocial society became the foundation for a large-scale social group to establish civilized social order for large-scale cooperation. Initially, a political group founded its prosocial religion, and not vice versa, so each political group had its own prosocial religion as local prosocial religion. Therefore, politics is defined as a civilized social order for large-group cooperation based on a shared imaginary prosocial society to enhance group survival chance under existential group-size pressure. Politics based on an imaginary prosocial society is a necessary cause for large-scale cooperation, because under existential group-size pressure, large-scale cooperation needs politics based on an imaginary prosocial society. Politics based on civilized social order manifested as government is a sufficient cause for large-scale cooperation, because under politics as government, all types of large-scale cooperation become possible.

With increasing intergroup competition later, existential intergroup competition pressure was added to existential group-size pressure. Existential group-size pressure and existential intergroup competition pressure are existential group pressure. Existential group pressure that reduces group survival chance is analogous to evolutionary pressure that reduces reproductive success. Political imagination that enhances group survival chance under existential group pressure is analogous to new biological trait that enhances reproductive success under evolutionary pressure. The political imagination in established politics is adaptive to existential group pressure, so it is not pathological.

This paper proposes that neuropolitics consists of politics type and politics learning. Politics types include sociality politics for intragroup relations and worldview politics for intergroup relations derived from the social brain [6] [7] [8] [9]. Sociality politics include collectivistic politics, individualistic politics, interdependent politics, and generativity politics. Worldview politics include territorial politics, competitive politics, and cooperative politics. Politics learning includes the political imagination learning and the political rationality learning. This paper proposes that the political evolution consists of the premodern imaginative politics starting from civilization, the modern rational imaginative politics starting from the Axial Age, and the postmodern diverse rational imaginative politics starting from the Information Revolution. The paper will discuss the evolutionary origin of politics in Section 2, politics type in Section 3, politics learning in Section 4, and the political evolution in Section 5.

\section{The Evolutionary Origin of Politics}

In the study using a suite of phylogenetic comparative methods to investigate the 
early evolution of religion of hunter-gatherer, Peoples, Duda, and Marlowe found the oldest trait of religion, present in the most recent common ancestors (pre-civilized hunters-gatherers) of present-day hunter-gatherers, was animism. Belief in an afterlife emerged, followed by shamanism. Ancestor worship and high gods who are active in human affairs were absent in early hunter-gatherer suggesting a deep history for the egalitarian nature of hunter-gatherer societies [10]. Ancestor worship and high gods emerged with the advent of the Agricultural Revolution which started civilization.

The religions for the pre-civilized hunter-gatherer society were animism, belief in afterlife, and shamanism, which are basically pro-individual religions to enhance individual survival chance under existential environmental pressure. Through theory of mind, the pre-civilized hunter-gatherer society invented pro-individual imaginary agents as supernatural agents to enhance individual survival chance under existential environmental pressure. With the egalitarian nature, the small-scale social groups in the pre-civilized hunter-gatherer society rarely had existential group pressure to maintain prosocial religions to enhance group survival chance under existential social pressure. As a result, the small-scale social groups in the pre-civilized hunter-gatherer society did not have prosocial religions of ancestor worship and high god to promote prosociality. The pre-civilized hunter-gatherer society had no political identity and organization. The prehistoric society may be similar to the modern Bushman in African's Kalahari Desert as described by Marshall Sahlins' “The Original Affluent Society" [11]. The hunter-gatherer society has small band groups. It is egalitarian and peaceful. Available food is actually fairly adequate for their modest need.

About 12,000 to 10,000 years ago, the Neolithic Revolution to domesticate plants and animals occurred. The technology in Neolithic Revolution allowed and required a large-scale social group to do the work together in a small area to produce domesticated plants and animals. About 5000 years ago, urban societies developed, resulting in the first civilizations in agricultural society with city-states as the basic units. Major agricultural society started from large rivers, such as Mesopotamia between Tigris and Euphrates Rivers, Egypt along Nile River, China along Yellow River, and India along Indus River. Meanwhile, nomadic society started from arid land and grassland outside of the river valleys. Large clans were developed in nomadic society with clans as the basic units. City-states and clans started civilization.

According to Dunbar, the proper manageable group size based on the human brain size is around 150 [5]. According to Dunbar, the network of brain regions that are involved in understanding others and group size is the social brain brain [6] [7] [8] [9]. We are biologically hard-wired for interacting instinctively with others. This instinctive social brain is located mainly in the neocortex in the outmost layer of the brain. The neocortex is much larger in humans as compared to other primates and mammals of similar size. The human instinctive so- 
cial brain is for the manageable group size around 150. City-states and clans had much larger populations than 150 people. A manageable large-scale civilized social group based on the instinctive social brain for the social group formation of the small-scale pre-civilized social group could not exist sustainably. To enhance group survival chance under such existential group-size pressure and existential intergroup competition pressure, large-scale civilized social groups invented imaginary prosocial societies which founded prosocial religions of ancestor worship and high gods to enforce prosociality. A civilized large-scale group simply combined the original imaginary agents in pro-individual religions with the new imaginary agents such as ancestors and high gods in prosocial religions, so ancestors and high gods could be both pro-individual and prosocial. This imaginary prosocial society became the foundation for a large-scale social group to establish civilized social order for large-scale cooperation. Therefore, politics is defined as a civilized social order for large-group cooperation based on a shared imaginary prosocial society to enhance group survival chance under existential group-size pressure. This politics is the premodern imaginative politics which is the base of all politics. The evolutionary origin of politics is shown in Figure 1. To existential group-size pressure, existential intergroup competition was added later, when intergroup competitions among city-states and clans became frequent.

In the premodern imaginative politics, imaginary agents (ancestors and high gods) in prosocial religions were described as seeking obedience and sacrifices, as enforcing political norms and authority [12]. During the Axial Age [13] from about the eighth to the third century BCE, the dominant regional powers under empires had lost their powers, and new ones were still not ready [14]. As a result, during the Axial Age, people started to question about imaginary agents and their rituals. Socrates said, "The unexamined life is not worth living." Rationality was added to imagination to form the modern rational imaginative politics. According to Max Weber, modernity is directly related to rationality [15].

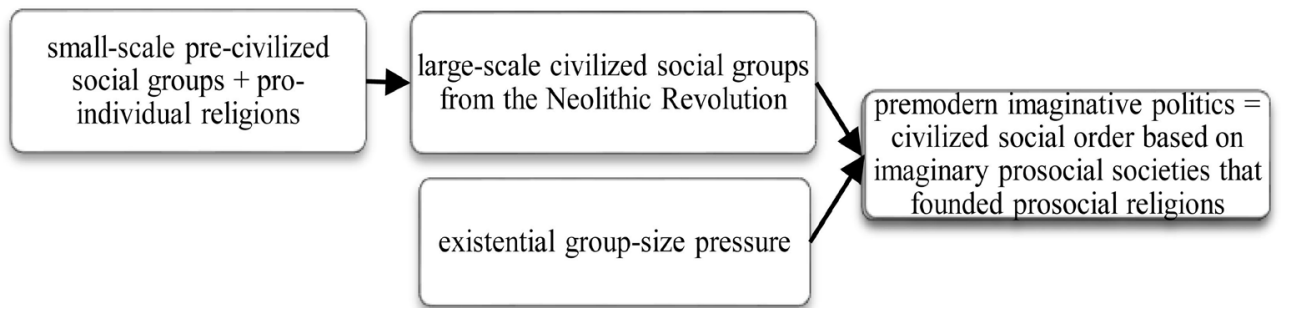

Figure 1. The evolutionary origin of politics: The pre-civilized hunter-gatherer society without politics consists of small-scale pre-civilized social groups and pro-individual religions, such as animism, belief in afterlife, and shamanism, to enhance individual survival chance under existential environmental pressure. The Neolithic Revolution started civilization with large-scale civilized social groups. Under existential group-size pressure, large-scale civilized groups invented imaginary prosocial societies which founded prosocial religions, such as ancestor worship and high gods, to enforce prosociality. This imaginary prosocial society became the foundation for a large-scale social group to establish civilized social order for large-scale cooperation. The result is the premodern imaginative politics which is the base of all politics. 
The political brain is derived from the social brain brain through imagination and rationality.

\section{Politics Type}

In this paper, neuropolitics includes politics type and politics learning. Politics types include sociality politics for intragroup relations and worldview politics for intergroup relations in the social brain [6] [7] [8] [9]. Political learning includes imagination learning and rationality learning.

\subsection{The Social Brain}

The political brain is derived from the social brain. The social brain consists of sociality for intragroup relations and worldview for intergroup relations [8]. In the social brain, sociality for intragroup relations consists of collectivistic, individualistic, interdependent, and generativity relations. Collectivistic relation benefits vulnerable children against neglect by forming kinship-friendship group [16] whose relations depend on commitment to a social group rather than reciprocal benefit of individuals. The origin of collectivistic sociality is the social group of caregivers and vulnerable children. Individualistic relation benefits vulnerable individuals against predation by forming alliance group [6] [7] whose relations depend on reciprocal benefit of individuals rather than commitment to a social group. The base of individualistic sociality is extensive and complex socialization. For primates, the brain size for individualistic sociality is proportional to the group size and the complexity of socialization.

Interdependent relation benefits vulnerable specialists against handicaps by forming specialist group from specialists whose relations dependent on existential division of labor [8] [17] [18]. The early hominins formed the interdependent specialists groups consisting of the forest group of homemaker-forager for women and children and the woodland group of explorer-forager for men in the mixed forest-woodland habitat. The handicap was the feet which were still suitable for climbing trees, and not suitable to walk long distance and run fast on the ground especially for pregnant women and small children in woodland area. Later, the division of labor became gatherer-hunter in open savanna habitat. Generativity relation benefits future generations by forming multiple-generation group whose relations depend on legacy [19] [20] [21] [22]. Unlike great apes, infertile women have long life after menopause allows multiple generations to live together. The caring of infertile women after menopause for their grandchildren and great-grandchildren is the base of legacy. The four sociality relations are collectivistic relation from kin-friends to benefit vulnerable children through commitment, individualistic relation from allies to benefit vulnerable individuals through reciprocity, interdependent relation from specialists to benefit vulnerable specialists through division of labor, and generativity relation from multiple generations to benefit vulnerable future generations through legacy as in Table 1. 
In the social brain, worldview is for intergroup relations based on ingroup and outgroup. In ingroup, individuals have similar interests and outlooks, and produce the feeling of connection among them [23]. Individuals in outgroup outside the boundary of one's own group are different in interests and outlook, and produce the feeling of zero-sum competition toward outgroup. The proper behavior as morality toward ingroup is cooperation, whereas the proper behavior toward outgroup is zero-sum competition [24]. Such ingroup-outgroup boundary instinct appears even in infants at few months old [25]. Worldview relations include territorial relation for ingroup-outgroup intergroup with clear boundary between ingroup and outgroup, competitive relation for outgroup-like intergroup without clear boundary between ingroup and outgroup, and cooperative relation for ingroup-like intergroup without clear boundary between ingroup and outgroup as shown in Table 2.

\subsection{From the Social Brain to the Political Brain}

The social brain is transformed into the political brain through imagination and rationality for large social group. Sociality politics for intragroup relations consists of collectivistic sociality politics, individualistic sociality politics, interdependent sociality politics, and generativity sociality politics. Worldview politics for intergroup relations consists of territorial worldview politics, competitive worldview politics, and cooperative worldview politics. The imaginative politics relates to religions, while the rational politics relates to secular politics. The religious examples for collectivistic sociality politics are Judaism and Confucianism that emphasize family, kinship, friends, and collectivistic welfare. The secular political example is socialism that emphasize in comradeship and collectivistic welfare. The religious example for individualistic sociality politics is Greek religion that emphasize in individual heroes and individualistic achievement. The secular political example is capitalism where each individual works for oneself. The religious examples for interdependent sociality politics are Christianity and

Table 1. Sociality for intragroup relations.

\begin{tabular}{cccc}
\hline Intragroup Relation & Intragroup & Beneficiaries & Principle \\
\hline collectivistic & kin-friends & vulnerable children & commitment \\
individualistic & allies & vulnerable individuals & reciprocity \\
interdependent & specialists & vulnerable specialists & division of labor \\
generativity & multiple generations & vulnerable future generations & legacy
\end{tabular}

Table 2. Worldview for intergroup relations.

\begin{tabular}{ccc}
\hline Intergroup Relation & Boundary & Intergroup \\
\hline Territorial & Clear & Ingroup-outgroup intergroup \\
Competitive & Unclear & Outgroup-like intergroup \\
Cooperative & Unclear & Ingroup-like intergroup \\
\hline
\end{tabular}


Daoism. Christianity emphasizes in interdependent relations within the church where everyone has a special calling from God. Daoism emphasizes the interdependence between yin and yang. The secular political example is the division of labor among various departments within a government. The examples for generativity sociality politics are religious legacy and political legacy transmitted from generations to generations.

Worldview politics consists of territorial, competitive, and cooperative politics. The religious example for territorial worldview politics is local religion which has clear ingroup-outgroup boundary. The secular political example is territorialism which has clear boundary. The religious examples for competitive worldview politics are the Abrahamic religions (Judaism, Christianity, and Islam) which do not tolerate and coexist peacefully with other religions. The secular political example is democracy based on election that is basically a zero-sum intergroup competition among different groups. The religious examples for cooperative worldview politics are the Eastern religions (Hinduism, Buddhism, Confucianism, and Daoism) that tolerate and coexist peacefully with other cooperative religions. The secular political example is meritocracy based merit which is essentially an intergroup cooperation among different groups. The summary of various politics is shown in Table 3.

\section{Politics Learning}

Politics learning consists of the political imagination learning and the political rational learning. Theory of mind is to recognize (imagine) that the others exist to think for themselves, so it relates to imagination. Autistic individuals with problems in imaginative capacities and pretend plays are incapable of theory of mind [26] [27] [28]. Thinking about God activates brain regions associated with theory of mind [29]. According to a PET study, theory of mind activates the medial prefrontal node to handle the mental state of the self, the superior temporal sulcus to detect the behavior of other animals and analyzes the goals and outcomes of this behavior, and the inferior frontal region to maintain representations of actions and goals [30]. Theory of mind supplies the cognitive basis for the belief in imaginary prosocial society to have its own mind in its own imaginary world.

Table 3. Politics for Intragroup and Intergroup Relations.

\begin{tabular}{cccc}
\hline Politics & Group & Imaginative politics examples & Rational politics examples \\
\hline Collectivistic sociality & Kin-friends intragroup & Judaism, Confucianism & Socialism \\
Individualistic sociality & Allies intragroup & Greek religion & Capitalism \\
Interdependent sociality & Specialists intragroup & Christianity, Daoism & Governmental division of labor \\
Generativity sociality & Multiple generation intragroup & Religious legacy & Political legacy \\
Territorial worldview & Ingroup-outgroup intergroup & Local religions & Territorialism \\
Competitive worldview & Outgroup-like intergroup & Abrahamic religions & Democracy \\
Cooperative worldview & Ingroup-like intergroup & Eastern religions & Meritocracy \\
\hline
\end{tabular}


The political rational learning includes the emotional-instinctive learning, the subjective rational learning, and the objective rational learning [31]. The emotional-instinctive learning locates in the subcortex and the limbic regions, and the neurotransmitters include endorphins for individualistic sociality and oxytocin for collectivistic sociality. Emotion and instinct are blunt and black-and-white reactions without discerning. They occur extremely rapidly before conscious thoughts. The subjective rational learning uses reasoning to defend the view derived from instinct and emotion against the opposite point of view. The subjective rational learning locates in the orbital frontal cortex for the processing of emotions, the anterior cingulate for conflict resolution, the posterior cingulate for making judgments about moral accountability, and the ventral striatum for reward and pleasure. The neurotransmitters are glutamine and dopamine. The objective rational learning locates in the dorsolateral prefrontal cortex for objective reasoning and analysis without bias. The neurotransmitter is glutamine. Political learning is described in Table 4.

Objective rationality plays a limited role in political decisions. According to Drew Westen [31], only between 0.5 and 3 percent of the most important political decisions utilize objective rationality. The combination of subjective rationality and objective rationality explains the dialectical progress. The three stages of the dialectical progress consist of a thesis to produce its reaction, an antithesis to contradict or negate the thesis, and the tension between the two being resolved by means of a synthesis. The three stages can be repeated with a new antithesis as in Figure 2.

The dialectical progress can be explained by the rational dialectical progress derived from subjective rationality and objective rationality. The three stages of the rational dialectical progress consists of a subjective rationality to produce its reaction, a subjective anti-rationality to contradict or negate the subjective

Table 4. Politics Learning.

\begin{tabular}{ccc}
\hline $\begin{array}{c}\text { Political rational } \\
\text { learning }\end{array}$ & Location & Neurotransmitter \\
\hline Emotion-instinct & Subcortex and limbic regions & $\begin{array}{c}\text { Endorphins and } \\
\text { oxytocin }\end{array}$ \\
Subjective rationality & $\begin{array}{c}\text { Orbital frontal cortex, anterior cingulate, posterior } \\
\text { cingulate, and ventral striatum }\end{array}$ & $\begin{array}{c}\text { Glutamine and } \\
\text { dopamine }\end{array}$ \\
Objective rationality & Dorsolateral prefrontal cortex & Glutamine \\
\hline
\end{tabular}

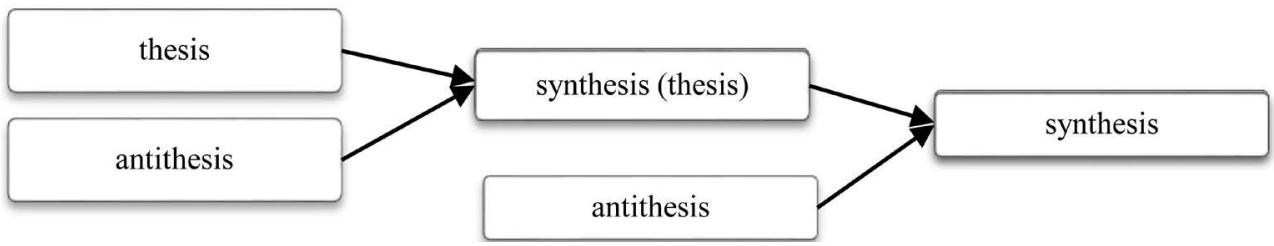

Figure 2. The dialectical progress: Antithesis against thesis results in synthesis which becomes thesis against another antithesis to produce another synthesis. 
rationality, and the tension between the two being resolved by means of an objective rationality. The new three stages can be repeated with a new subjective anti-rationality as in Figure 3. The political progress can be made only by the rational dialectical progress. One example is the Marx's dialectical progress which is the rational political progress within collectivistic sociality resulting in the totally collectivistic (classless) society as the final synthesis (objective rationality).

\section{The Political Evolution}

In biological evolution, a most important factor in evolution is habitat. Different species were evolved in different habitats. In the same way, different politics have been evolved in different political habitats. A most important factor in political habitat is the size of political involvement. Different political habitats with different sizes of political involvement require different politics. As human civilization advances, the size of political involvement inevitably increases in the order of premodern large-scale local society habitat, modern large-scale regional society habitat, and postmodern large-scale global society habitat. As the political habitat changes, an old politics may not change with new habitat, but the actual political practice of citizens in their daily life changes with new habitat willingly or reluctantly. This paper proposes that the politics consist of the imaginative politics for premodern large-scale local society habitat starting from civilization, the rational imaginative politics for modern large-scale regional society habitat starting from the Axial Age, and the diverse rational imaginative politics for postmodern large-scale global society habitat starting from the Information Revolution.

\subsection{The Premodern Imaginative Politics}

Under existential group-size pressure, large-scale civilized social groups invented imaginary prosocial society through theory of mind. Imaginary prosocial society can be personal and/or impersonal. The personal prosocial society turns into the great ancestor (forefather)-god politics to exaggerate the greatness and the relatedness of ancestor (forefather) and god, while the impersonal prosocial society turns into the great nation politics to exaggerate the greatness and the relatedness of nation. One example of great god politics is the prosocial religion based on Big Gods [2]. Great ancestor-god politics and great nation politics are

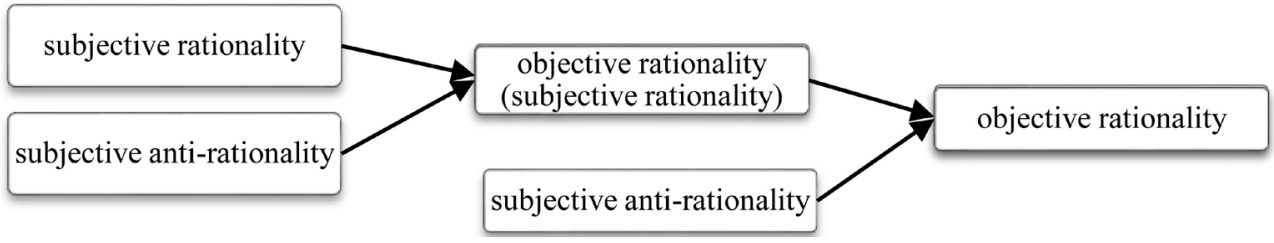

Figure 3. The rational dialectical progress: Subjective anti-rationality against subjective rationality results in objective rationality which becomes subjective rationality against another subjective anti-rationality to produce another objective rationality. 
maintained by elaborate rituals, monuments, educations, and propagandas. In terms of the social brain, an imaginary prosocial society is essentially to exaggerate the attractiveness of large-scale ingroup to generate great ancestor-god politics and great nation politics.

About 5000 years ago, urban societies developed, resulting in the first civilizations in agricultural society with city states as the basic political units. Major agricultural society started from large rivers, such as Mesopotamia between Tigris and Euphrates Rivers, Egypt along Nile River, China along Yellow River, and India along Indus River. Meanwhile, nomadic society started from arid land and grassland outside of the river valleys. Large clans were developed in nomadic society with clans as the basic political units. Initially, there were clear boundaries among the basic political units. People were clearly loyal to their city states or clans. They had territorial worldview. The further advance of technology and the increase in population and wealth increased the interactions among multiple city-states/clans, resulting in the continuous merges and splits of city-states/clans that destroyed clear boundaries. Territorial worldview with clear boundary was transformed into competitive worldview or cooperative worldview without clear boundary.

Agricultural society and nomadic society developed different worldviews. In sedentary agricultural society, the main economic growth model was the economic gain in agricultural products from the investment in the complex infrastructures, such as market, transportation, and irrigation. The infrastructure involves both basic physical and organizational structures-facilities. Agricultural society was motivated to form alliances in order to connect the infrastructures among city-states. As a result, agricultural society developed cooperative worldview to view the world as connective city-states. In mobile nomadic society without a fixed settlement for the complex infrastructures, the main economic growth model was the economic gain from the plundering of properties by conquest. The plundering of properties by conquest in nomadic society generated the competitive world, so nomadic society developed competitive worldview to view the world consisting of competitive clans.

The history of worldview is the history of the West originated from the Middle East and Greece and the East originated from India and China. Nomadic society by itself did not have enough people and natural resource to establish great civilization, but in the West, the nomadic society conquered the agricultural society, and established competitive worldview in the conquered agricultural society. The two groups of nomads in the West were the Semitic nomads and the Eurasian nomads. In the West, the agricultural Middle Kingdom (2120-1780 BC) of Egypt was conquered by a Semitic nomad, Hyksos. The agricultural Sumer was conquered by Akkad related to Semitic nomad outside of Sumer. After the conquests by the nomads, both Egypt (the New Kingdom 1550-1069 BC) and Mesopotamia (the Akkadian Empire 2350-2150 BC) turned into aggressive imperialistic empires with competitive worldview. (The Middle Kingdom and Su- 
mer were not imperialistic.) Afterward, competitive worldview has been firmly established in the West. In agricultural Indus Valley and Yellow River Valley, the cooperative worldview of agricultural society reversed or resisted competitive worldview of the invading nomads. The East has not developed permanently aggressive imperialistic empires with competitive worldview as neither China nor India has reached beyond Asia. The competitive West pursues global military hegemony by defeating competitors in the perceived competitive world, while the connective East pursues regional community to build the adaptable infrastructure for clothing, food, shelter, and transportation in the perceived cooperative world. The pre-civilized -premodern political evolution is shown in Figure 4.

\subsection{The Modern Politics}

The modern politics is the modern rational imaginative politics based on imagination-rationality. According to Max Weber, modernity is directly related to rationality [15]. Human capacity of reasoning in the frontal lobe of the neocortex for the rational brain allows human society to develop rational system. The modern rational imaginative politics is derived from the combination of the premodern imaginative politics and the rational systems.

The Agricultural-Nomadic Revolution transformed small band society into large-scale local society. In a large region, a dominating empire conquered large-scale local societies to form one large-scale regional society with many different traditions from the previous local societies. Under a tightly controlled regional society under an empire, such conflicts could be controllable. When an empire in a regional society lost its control, the regional society became chaotic. Under this chaotic situation, objective rationality occurred to resolve the conflicts among the conflicting subjective rationalities, resulting in the Axial Age. During the Axial Age [13] from about the eighth to the third century BCE, the dominant regional powers had lost their powers, and new ones were still not ready [14]. For an example, during the Axial Age, the dominant regional power Zhou in the China region was disintegrated, and the established religion and politics lost their powers, and local politics from local societies took over. The objective rational thinkers, such as Buddha, Confucius, Laozi, Socrates, Plato, and Aristotle, offered their objective rational systems to resolve the conflicts among the subjective rational systems from local societies. In the West, modernity

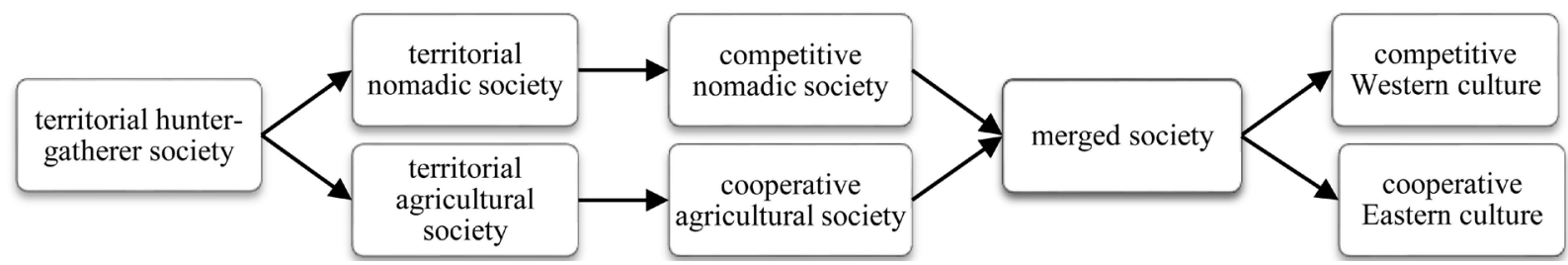

Figure 4. The premodern political evolution: Territorial hunter-gatherer society was transformed into territorial agricultural-nomadic society with clear boundaries. Without clear boundaries, nomadic society adopted competitive worldview, while agricultural society adopted cooperative worldview. The merge of both societies produced the Western culture to adopt competitive worldview and the Eastern culture to adopt cooperative worldview. 
reappeared during the Renaissance (about 1420-1630). The Renaissance was influenced by classical Greek philosophy. A founder of modernity is Rene Descartes (1596-1650) who promoted independent reason (I think, therefore I am).

For politics, the conflicts among the subjective rationalities of different local social groups were resolved by objective rationalities, such as democracy based on zero-sum competitive worldview and meritocracy based on cooperative worldview to resolve the intergroup conflicts. In the competitive West, democracy based on competitive election appeared at Athens during the Axial Age. In the cooperative East, China has practiced meritocracy based on cooperative merit system more or less continuously since the Axial Age.

The Industrial Revolution changed the agricultural social structure into the industrial social structure. The wealth moved from agricultural landlord to industrial capitalists, and the works moved from agricultural farm workers to industrial worker. Consequently, for domestic politics, individualistic sociality produced capitalism, while collectivistic sociality generated socialism. The rational formations of democracy and meritocracy can be explained by the rational dialectical progress derived from the conflict between collectivistic sociality (socialism and centralized power controlled by social group) and individualistic sociality (capitalism and decentralized power controlled by individuals). For democracy, the first three stages of the rational political dialectical progress consists of individualistic sociality subjective rationality to produce its reaction, collectivistic sociality subjective anti-rationality to contradict the individualistic sociality subjective rationality; and the tension between the two being resolved by means of competitive multi-party democracy objective rationality. The second three stages of the political dialectical progress consist of democracy (competitive worldview) subjective rationality to produce its reaction, meritocracy (cooperative worldview) subjective anti-rationality to contradict the democracy subjective rationality; and the tension between the two being resolved by the means of the mixed merito-democracy objective rationality. Such mixed merito-democracy appears in Europe and America by introducing merit-based bureaucrat-selection mechanism for civil service in democratic government. The rational political dialectical progress in democracy is shown in Figure 5.

The political dialectical progress for meritocracy occurs to form mixed

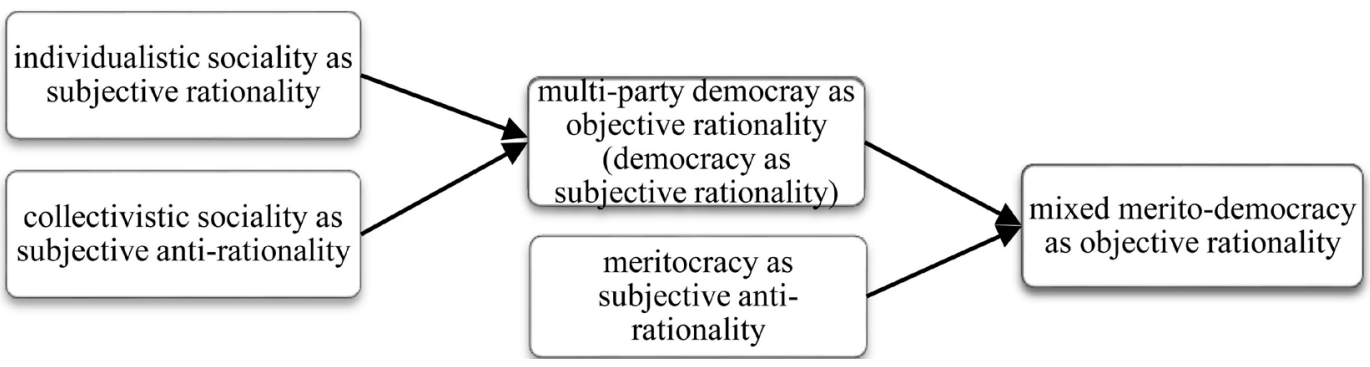

Figure 5. The rational dialectic progress for democracy: The contradiction between individualistic sociality and collectivistic sociality produces democracy. The combination of democracy and meritocracy produces mixed merito-democracy. 
demo-meritocracy as in China recently [32]. In China, the first three stages of the rational political dialectical progress consisted of collectivistic sociality subjective rationality (socialism) to produce its reaction, individualistic sociality subjective anti-rationality (private owned enterprises) to contradict the collectivistic sociality subjective rationality forty years ago; and the tension between the two being resolved by means of cooperative one-party meritocracy objective rationality to determine cooperatively the merit of collectivistic sociality and individualistic sociality on a case-by-case basis carefully. The second three stages of the political dialectical progress consist of meritocracy (cooperative worldview) subjective rationality to produce its reaction, democracy (competitive worldview) subjective anti-rationality to contradict the meritocracy subjective rationality; and the tension between the two being resolved by the means of the mixed demo-meritocracy objective rationality to have democracy in the local level government and meritocracy in the higher level government. The political dialectical progress for meritocracy is shown in Figure 6.

In the West, the zero-sum democratic competition between the right-wing capitalism and the left-wing socialism results in the political changes periodically. The frequent political changes result in the policies with the mixture of individualistic controlled economy and collectivistic controlled economy. In the East, particularly in China, the cooperation between capitalism and socialism results in the mixture of policies for individualistic controlled economy and collectivistic controlled economy depending on the merit of each policy. The results of democracy and meritocracy are the same, as both systems produce the mixture of individualistic controlled economy and collectivistic controlled economy. The processes are different. Democracy is more chaos-prone and less corruption-prone, while meritocracy is less chaos-prone and more corruption-prone. The mixture of democracy and meritocracy minimizes the problems considerably.

The political breakdown of Christendom control by Christian church in Europe resulted in the Thirty Years' War (1635-1659) among various Protestant and Catholic states. The conclusion of the war was that clear national boundaries were needed to allow each nation to decide ingroup and outgroup in terms of religious preferences of the nations. The rational-territorial system with clear

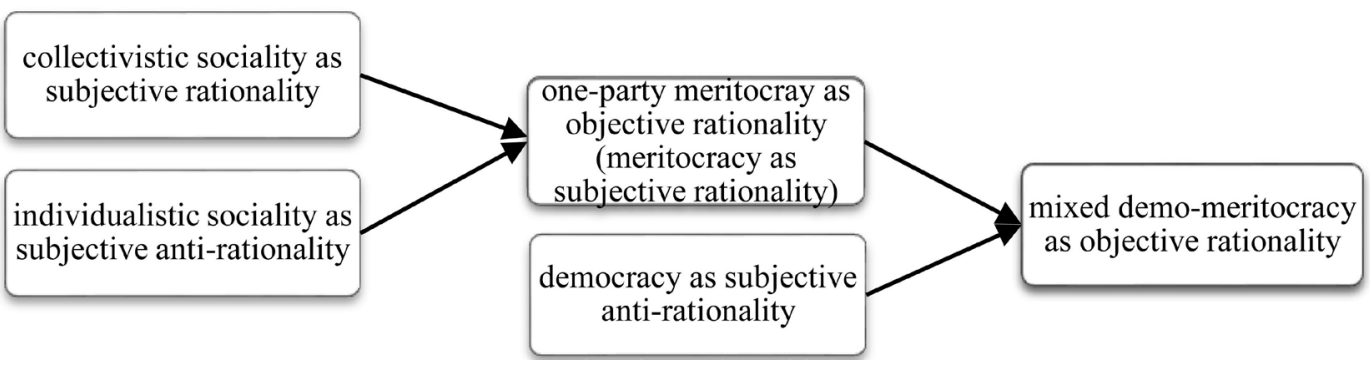

Figure 6. The rational dialectic progress for meritocracy: The contradiction between collectivistic sociality and individualistic sociality produces meritocracy. The combination of meritocracy and democracy brings about mixed demo-meritocracy. 
boundary was a rational adaptation to the breakdown of Christendom. The rational-territorial system defines ingroup and outgroup based on political-geographic boundary or ethnic-geographic boundary. All modern nations and international regional communities incorporate territorialism in various degrees depending on the importance of boundary. For nations, individualistic territorialism is civil nationalism with geopolitical boundary. Collectivistic territorialism is ethnic nationalism with both geopolitical boundary and ethnic boundary, and all citizens in ethnic nationalism are united under one dominant ethnic group.

Different rational international intergroup politics are derived from different worldviews [33]. For rational international intergroup politics, an important theory for Western international politics is John Mearsheimer's offensive international politics from offensive realism [34] posits that the international system is perceived realistically as the competitive anarchic international system. In the competitive anarchic international system, all states possess some offensive military capability, and states can never be certain of the intentions of other states. States have survival as their primary goal. States are rational actors who are capable of coming up with sound strategies that maximize their prospects for survival by military offense capable of defeating other states. The result of offensive realism is offensive international politics involving inevitably and tragically wars and conflicts as described in John Mearsheimer's "The Tragedy of Great Power Politics" [34]. Offensive international politics eventually leads to hegemonic domination. For competitive worldview, the international stability can be achieved by hegemonic domination in terms of dominating country and dominating political-economic system.

The second realism is infrastructural realism which perceives realistically the international system as the disconnected anarchic international system. In the disconnected anarchic international system, all states with some goods and service capability require international trade to survive and prosper, and states can never be certain of the intentions of other states. States have survival and prosperity as their primary goals. States are rational actors, capable of coming up with sound connective infrastructure for international trade that maximize their prospects for survival and prosperity, resulting in infrastructural realism for infrastructural international politics. The main international politics is economical instead of military, so the main military strategy is low-profile defense instead of high-profile offense as in offensive international politics. Throughout history, infrastructure has been central to national and international cohesion and economic growth, connecting countries to themselves and to one another. In China, historically, trades and intermarriages among agricultural group and surrounding nomad groups were common and encouraged most of times, resulting in the famous Silk Road. The recent One Belt, One Road (OBOR) is a current version of infrastructural international politics. Infrastructural international politics eventually leads to infrastructural connection to connect all nations. For cooper- 
ative worldview, the international stability can be achieved by infrastructural connection to connect all nations.

The third realism is territorial national-regional realism which perceives realistically the international system as the unclear boundary anarchic international system. In the unclear boundary anarchic international system, all states possess some national-regional boundaries, and states can never be certain of the intentions of other states. States have survival as their primary goal. States are rational actors, capable of coming up with clear national-regional boundaries that maximize their prospects for survival, resulting in territorial realism for territorial international politics. All nations enforce national territorial international politics. Some regions enforce regional territorial international politics, such as the Western Hemisphere's "Monroe Doctrine" that forbids military intervention from the countries outside of the Western Hemisphere. Territorial international politics eventually leads to protective borders for all all nations. For territorial worldview, the international stability can be achieved by protective borders for all nations.

In summary, the three different international politics are offensive international politics from competitive worldview, infrastructural international politics from connective worldview, and territorial international politics from territorial worldview. The three international politics are the subjective rationalities from their own subjective worldviews. The domestic and international intergroup politics are listed in Table 5.

\subsection{The Postmodern Politics}

In the late $20^{\text {th }}$ century [35], the Information Revolution started involving extensively computers and wired and wireless networks to store, manipulate, and transmit information. Global communication through information technology allows global interdependence in terms of global division of labor. Different countries specialize in producing different goods, services, and raw materials. Today, very few products are manufactured entirely in a single country, and people consume products daily from all over the world. The result is global interdependence. The combination of global interdependence and global information network leads to globalization, which combines with global multiple

Table 5. The rational domestic and international intergroup politics.

\begin{tabular}{cccc}
\hline Worldview & $\begin{array}{c}\text { Domestic Intergroup } \\
\text { Politics }\end{array}$ & $\begin{array}{c}\text { International } \\
\text { Intergroup Politics }\end{array}$ & $\begin{array}{c}\text { International } \\
\text { Intergroup Stability }\end{array}$ \\
Competitive & Democracy & Offensive & $\begin{array}{c}\text { Hegemonic } \\
\text { domination }\end{array}$ \\
Cooperative & Meritocracy & Infrastructural & $\begin{array}{c}\text { Infrastructural } \\
\text { connection }\end{array}$ \\
Territorial & Territorialism & Territorial & Protective border \\
Competitive-connective & Demo-meritocracy and & None & None \\
\hline
\end{tabular}


cultures resulting in global cultural diversity. The combination of global cultural diversity and the modern rational imaginative politics brings about the postmodern diverse rational imaginative politics.

The global diversity particularly affects international intergroup politics. Different worldviews produce different ways to achieve international political stability. The international intergroup stability can be reached by hegemonic domination subjective rationality for competitive worldview, infrastructural connection subjective rationality for cooperative worldview, or protective border subjective rationality for territorial worldview. For competitive worldview, all nations compete militarily, economically, and politically. The result is international intergroup instability. The way to achieve international intergroup stability is through hegemonic domination, militarily, economically, and politically. To achieve hegemony, hegemons have high military spending, dominating offensive weapons, ubiquitous overseas military bases, military alliances, overseas proxy wars, military interventions, and the enforcement of dominating political and economic systems. For cooperative worldview, all nations are insufficient in all natural and human resources all the time. Such insufficiency causes intragroup instability which produces international intergroup instability. The way to achieve international intergroup stability is through infrastructural connection to help one another in natural and human insufficiencies. To achieve infrastructural connection requires high infrastructure spending, high infrastructural technology, and global trade. For territorial worldview, all nations are insecure in their borders. The insecure borders produce international intergroup instability. The way to achieve international intergroup stability is through protective border. To achieve protective border requires strong border barrier, minimum immigration, and selective foreign visitors.

The three subjective rationalities to achieve international stability contradict or negate one another. Hegemonic domination contradicts infrastructural connection which allows diversity in military, economy, and politics, and negates protective border which does not allow foreign military interventions and overseas military bases. Infrastructural connection contradicts protective border which prefers strong border barrier. To resolve the conflicts among these three subjective rationalities requires the international intergroup objective rationality consisting of the competitive, cooperative, and territorial worldview components which do not contradict or negate one another, and are complementary one another. The international intergroup objective rationality consists of competitive global free trade in economy, cooperative global infrastructural connection for development, and territorial national-regional protective borders in military defense as shown in Figure 7.

Competitive global free trade benefits trading countries where each country develops its own comparative advantage in international trade. Competitive free trade provides economic growth as shown in higher economic growth for the countries with free trade than the countries with protectionism. The companies 


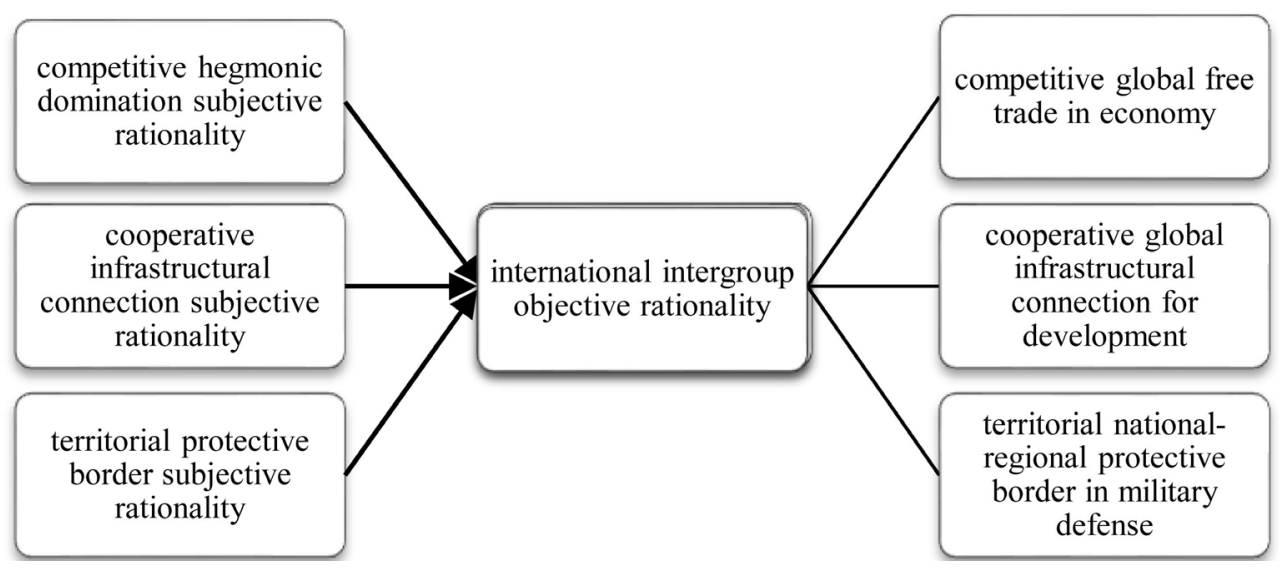

Figure 7. The rational political dialectical progress for international intergroup politics: The three international intergroup politics (competitive hegemonic domination, cooperative infrastructural connection, and territorial protective border) subjective rationalities contradict and negate one another. The rational political dialectical progress involves the formation of international intergroup objective rationality consisting of competitive global free trade in economy, cooperative global infrastructural connection in infrastructure, and territorial national-regional protective border in military defense.

in competitive global free trade consist of individualistic private ownership companies and collectivistic state ownership companies. The major companies before the collapse of the USSR were mostly individualistic private ownership companies by early industrial countries such as European countries and America. Afterward, the newly developed countries such as India, Russia, Turkey, China, Arab, and Brazil have a mixture of individualistic private ownership companies and collectivistic state ownership companies [36]. Each type of companies has its advantages and disadvantages. In general, individualistic private ownership companies are innovative but not stable, and collectivistic state ownership companies are stable but not innovative, so they are complementary to allow both innovation and stability which are important for healthy economy. As a result, all competitive (non-monopolized) companies are in competitive global free trade.

However, the benefit from competitive global free trade is volatile and short-term. Competitive global free trade is necessary to complement with cooperative global infrastructural connection that is stable and long-term, and allows each country to develop both international and domestic markets. However, competitive global free trade and cooperative global infrastructural connection require protection, so are necessary to complement with territorial national-regional protective borders in military defense to protect from military intrusion.

The establishment of the religious-geographic borders ended the religious war in the Thirty Years' War among Protestant and Catholic states. In the same way, the establishment of the cultural-geographic borders will end the cultural clash among cultural types. As a result, the establishment of the rational territorial national-regional protective borders consisting of nations with geopolitical borders 
and the regional communities with cultural-geographic borders can avoid global conflicts. The regional communities exist in the "World Regional Community Organization" (the WRCO) where every country in the world belongs to a regional community [33]. The countries in one geographic region can find common identities to establish one regional community. The common identities of a regional community include some or all of the shared geography region, shared existing regional international organization, shared dominant cultural-religion, shard dominant language, shared dominant sociality, and shared dominant worldview. Each regional community has at least one economically strong country for its protection and strength. The 12 communities in the World Regional Community Organization (WRCO) are as follows and in Table 6.

The North American Community

Canada, Mexico, the USA.

The South American Community

Antigua and Barbuda, Argentina, Bahamas, Barbados, Belize, Bolivia, Brazil, Chile, Colombia, Costa Rica, Cuba, Dominica, Dominican Republic, Ecuador, El Salvador, Grenada, Guatemala, Guyana, Haiti, Honduras, Jamaica, Nicaragua, Panama, Paraguay, Peru, St. Kitts and Nevis, St. Lucia, St. Vincent and The Grenadines, Suriname, Trinidad and Tobago, Uruguay, Venezuela.

\section{The East Asian Community}

China, Japan, Mongolia, Philippines, the Republic of Korea, the Democratic People's Republic of Korea, Vietnam.

The South Asian Community

Bangladesh, Bhutan, Brunei, Cambodia, Laos, Malaysia, Singapore, India, Indonesia, Maldives, Myanmar, Nepal, Sri Lanka, Thailand, Timor-Leste.

The Midwest Asian Community

Afghanistan, Iran, Iraq, Pakistan, Syria, Turkey.

The Southwest Asian Community

Bahrain, Israel, Jordan, Lebanon, Kuwait, Oman, Palestine, Qatar, Saudi Arabia, the United Arab Emirates, Qatar, Yemen.

The Eurasian Community

Armenia, Azerbaijan, Belarus, Georgia, Kazakhstan, Kyrgyzstan, Russia, Tajikistan, Turkmenistan, Uzbekistan.

The West European Community

Albania, Andorra. Austria. Belgium. Bosnia and Herzegovina, Bulgaria. Croatia. Cyprus. Czech Republic, Denmark, Estonia, Finland, France, Germany, Greece, Hungary, Iceland, Ireland, Italy, Kosovo, Latvia, Liechtenstein, Lithuania, Luxembourg, Macedonia, Malta, Moldova, Monaco, Montenegro, Netherlands, Norway, Poland, Portugal, Romania, San Marino, Serbia, Slovakia, Slovenia, Spain, Sweden, Switzerland, Ukraine, the United Kingdom, Vatican City.

The North African Community

Algeria, Comoros, Burkina Faso, Djibouti, Egypt, Gambia, Guinea, Guinea-Bissau, Libya, Mali, Mauritania, Morocco, Niger, Senegal, Sierra Leone, Somalia, Sudan, Tunisia, Western Sahara. 
Table 6. The world regional community organization (WRCO).

\begin{tabular}{|c|c|c|c|c|c|c|}
\hline $\begin{array}{l}\text { Regional } \\
\text { community }\end{array}$ & $\begin{array}{l}\text { Major } \\
\text { country }\end{array}$ & $\begin{array}{l}\text { Major existing } \\
\text { organization }\end{array}$ & $\begin{array}{c}\text { Major cultural-religious } \\
\text { influence }\end{array}$ & Major languages & $\begin{array}{l}\text { Major } \\
\text { sociality }\end{array}$ & $\begin{array}{c}\text { Major } \\
\text { worldview }\end{array}$ \\
\hline North American & USA & NAFTA & Christianity & English-Spanish & Individualistic & Competitive \\
\hline South American & Brazil & OAS & Christianity & Spanish-Portuguese & Individualistic & Territorial \\
\hline East Asian & China & & Confucianism & Mixed languages & Collectivistic & Cooperative \\
\hline South Asian & India & ASEAN & Indian culture & Mixed language & Collectivistic & Cooperative \\
\hline Midwest Asian & Turkey & & Islam & Mixed language & Collectivistic & Competitive \\
\hline Southwest Asian & Saudi Arabia & Arab League & Islam & Arabic & Collectivistic & Competitive \\
\hline Eurasian & Russia & EAEU & Christianity-Islam & Russian & Collectivistic & Cooperative \\
\hline West European & Germany & $\mathrm{EU}$ & Christianity & Mixed language & Individualistic & Competitive \\
\hline North African & Egypt & Arab League, ECOWAS & Islam & Mixed language & Collectivistic & Territorial \\
\hline West African & Nigeria & ECOWAS and ECCAS & Christianity & Mixed language & Collectivistic & Territorial \\
\hline $\begin{array}{l}\text { East-South } \\
\text { African }\end{array}$ & South Africa & $\begin{array}{c}\text { COMESA, EAC, and } \\
\text { SADC }\end{array}$ & Christianity & Mixed language & Collectivistic & Territorial \\
\hline $\begin{array}{l}\text { Pacific Islands } \\
\text { Forum }\end{array}$ & Australia & $\begin{array}{l}\text { Pacific Islands Forum } \\
\text { Community }\end{array}$ & Christianity & English & Individualistic & Competitive \\
\hline
\end{tabular}

\section{The West African Community}

Benin, Cape Verde, Cameroon, Central African Republic, Chad, Côte d'Ivoire, Democratic Republic of the Congo, Equatorial Guinea, Gabon, Ghana, Liberia, Nigeria, Republic of the Congo, São Tomé and Príncipe, Togo.

The East-South African Community

Angola, Botswana, Burundi, Eritrea, Ethiopia, Kenya, Lesotho. Madagascar, Malawi. Mauritius, Mozambique, Namibia, Rwanda, Seychelles, South Africa, South Sudan, Swaziland, Tanzania, Uganda, Zambia, Zimbabwe.

\section{Pacific Islands Forum Community}

Australia, Fiji, Kiribati, Marshall Islands, Micronesia, Nauru, New Zealand, Palau, Papua New Guinea, Samoa, Solomon Islands, Tonga, Tuvalu, Vanuatu.

With the territorial regional protective border, each regional community enforces the "Monroe Doctrine" that forbids military intrusion from the countries outside of a regional community except the intervention approved by the United Nations. As a result, all overseas military bases as the military intrusion from the countries outside of a regional community have to be abolished. All defense treaties connected to the countries outside of a regional community also have to be ended. All intercontinental ballistic missiles have to be eliminated. The numbers of aircraft carriers have to be strictly limited to few aircraft carriers according to the area of adjacent oceans. Horrible inhuman nuclear weapons have to be abolished. Stealth aircrafts that are basically for stealth air offence should also be eliminated. Therefore, only weapons allowed are short-distant, non-nuclear, and non-stealth defensive weapons. With the very limited weapons and overseas military bases, the military spending can be easily cut to maximum $2 \%$ of GDP and 
then for further reduction in the same way as the gradual reduction of tariff by the WTO (World Trade Organization). The saving from destructive offensive military spending can be used in constructive infrastructure. The regional communities which are for military defense allow individual nations to maintain all international economic treaties inside and outside of the communities. Different regional communities will have different degrees of economic cooperation within the communities.

\section{Conclusions}

In summary, the evolutionary origin of politics is based on imaginary prosocial societies for large-scale cooperation at the beginning of civilization established by large-scale civilized social groups. The size of the human brain is adapted to the manageable group size of about 150 people (Dunbar's Number). A manageable large-scale civilized social group much more than 150 people could not exist sustainably. To enhance group survival chance under such existential group-size pressure, large-scale civilized social groups invented imaginary prosocial societies which founded prosocial religions of ancestor worship and high gods to enforce prosociality. (In modern times, imaginary prosocial societies founded secular nationalisms with elaborate rituals, monuments, and devotions to enforce prosociality.) This imaginary prosocial society became the foundation for a large-scale social group to establish a civilized social order for large-scale cooperation. Therefore, politics is defined as a civilized social order for large-group cooperation based on a shared imaginary prosocial society to enhance group survival chance under existential group-size pressure. Existential intergroup competition pressure emerged later with increasing intergroup competition.

Neuropolitics consists of politics type and politics learning. Politics types include sociality politics for intragroup relations and worldview politics for intergroup relations derived from the social brain. Sociality politics include collectivistic politics, individualistic politics, interdependent politics, and generativity politics. Worldview politics include territorial politics, competitive politics, and cooperative politics. For intragroup politics, individualistic sociality produces capitalism, while collectivistic sociality produces socialism. For domestic and international intergroup politics, competitive worldview produces democracy and hegemonic domination, cooperative worldview produces meritocracy and infrastructural connection, and territorial worldview produces territorialism and protective border.

Politics learning includes the political imagination learning and the political rationality learning. The political rationality is derived from the rational brain that generates subjective rationality to defend a political view and objective rationality to create a new political view dialectically. Progress in politics can be made through the rational dialectical progress. Through the rational dialectical progress, the objective rationality in global international intergroup politics consists of competitive global free-trade in economy, cooperative global infrastruc- 
tural connection for development, and territorial national-regional protective border in military defense.

The political evolution consists of the premodern imaginative politics starting from civilization, the modern rational imaginative politics starting from the Axial Age, and the postmodern diverse rational imaginative politics starting from the Information Revolution. The politics based on imaginary prosocial society is imaginative politics. The political imagination is derived from theory of mind that generates an imaginary prosocial society to have its own mind in its own imaginary world. Imagination is the mental ability to produce images, thoughts, and feelings independent of immediate input perceptions such as vision and hearing. Imaginary prosocial society is the prosocial society beyond any perceived prosocial society. During the Axial Age, rationality was added to form the modern rational imaginative politics starting from the Axial Age. Global diversity is added to form the postmodern diverse rational imaginative politics starting from the Information Revolution. Global diversity is derived from the combination globalization and global multiple cultures.

In conclusion, neuropolitics as the combination of neuroscience and political science is based on the political brain derived from the social brain through imagination and rationality. It explains the evolutionary origin of politics, the political evolution, politics types, and politics learnings. Politics is a necessary and sufficient cause for large-scale cooperation. The best global cooperation requires the best political imagination and the best political rationality.

\section{Conflicts of Interest}

The author declares no conflicts of interest regarding the publication of this paper.

\section{References}

[1] Schreiber, D. (2017) Neuropolitics: Twenty Years Later. Politics and the Life Sciences, 36, 114-131. https://doi.org/10.1017/pls.2017.25

[2] Norenzayan, A., et al. (2016) The Cultural Evolution of Prosocial Religions. Behavioral and Brain Sciences, 39, e1. https://doi.org/10.1017/S0140525X14001356

[3] Norenzayan, A. and Gervais, W. (2012) The Cultural Evolution of Religion. In: Slingerland, E. and Collard, M., Eds., Creating Consilience: Integrating the Sciences and the Humanities, Oxford University Press, Oxford, UK, 243-265.

[4] Norenzayan, A. (2015) Big Questions about Big Gods: Response and Discussion. Religion, Brain and Behavior, 4, 327-342. https://doi.org/10.1080/2153599X.2014.928359

[5] Dunbar, R. (1993) Coevolution of Neocortex Size, Group Size and Language in Humans. Behavioral and Brain Sciences, 16, 681-735. https://doi.org/10.1017/S0140525X00032325

[6] Dunbar, R. (2009) The Social Brain Hypothesis and Its Implications for Social Evolution. Annals of Human Biology, 36, 562-572. https://doi.org/10.1080/03014460902960289

[7] Dunbar, R. (2016) The Social Brain Hypothesis and Human Evolution. Oxford Research Encyclopedia of Psychology. 
https://doi.org/10.1093/acrefore/9780190236557.013.44

[8] Chung, D. (2018) The Mental Protection System for Protective Behaviors: The Social Brain and the Mental Immune System. Journal of Behavioral and Brain Science, 8, 31-55. https://doi.org/10.4236/jbbs.2018.81003

[9] Cozolino, L. (2006) The Neuroscience of Human Relationships: Attachment and the Developing Social Brain. W. W. Norton \& Co., New York.

[10] Peoples, H., Duda, P. and Marlowe, F. (2016) Hunter-Gatherers and the Origins of Religion. Human Nature, 27, 261-282. https://doi.org/10.1007/s12110-016-9260-0

[11] Sahlins, M. (1968) Notes on the Original Affluent Society. In: Lee, R. and DeVore, I., Eds., Man the Hunter 85-89, Aldine de Gruyter, New York.

[12] Bellah, R.N. (2011) Religion in Human Evolution: From the Paleolithic to the Axial Age. Harvard University Press, Cambridge, Massachusetts. https://doi.org/10.4159/harvard.9780674063099

[13] Meister, C. (2009) Introducing Philosophy of Religion. Routledge, Abingdon, 10. https://doi.org/10.4324/9780203880029

[14] Thomassen, B. (2010) Anthropology, Multiple Modernities and the Axial Age Debate. Anthropological Theory, 10, 321-342. https://doi.org/10.1177/1463499610386659

[15] Larraín, J. (2001) Identity and Modernity in Latin America. Blackwell Publishing, Malden, Massachusetts.

[16] Hamilton, W. (1964) The Genetical Evolution of Social Behavior II. Journal of Theoretical Biology, 7, 17-52. https://doi.org/10.1016/0022-5193(64)90039-6

[17] Wilson, E.O. (2012) The Social Conquest of the Earth. W.W. Norton \& Company, New York.

[18] Chung, D. (2016) The Basic Principles of Kin Sociality and Eusociality: Human Evolution. Natural Science, 8, 8-19. https://doi.org/10.4236/ns.2016.81002

[19] Erikson, E. and Erikson, J. (1998) The Life Cycle Completed. W.W. Norton \& Company, New York.

[20] Slater, C.L. (2003) Generativity versus Stagnation: An Elaboration of Erikson's Adult Stage of Human Development. Journal of Adult Development, 10, 53-65. https://doi.org/10.1023/A:1020790820868

[21] McAdams, D. and De St. Aubin, E. (1992) A Theory of Generativity and Its Assessment through Self-Report, Behavioral Acts, and Narrative Themes in Autobiography. Journal of Personality and Social Psychology, 62, 1003-1015. https://doi.org/10.1037/0022-3514.62.6.1003

[22] Chung, D.Y. (2018) The Eight Stages of Psychosocial Protective Development: Developmental Psychology. Journal of Behavioral and Brain Science, 8, 369-398. https://doi.org/10.4236/jbbs.2018.86024

[23] Turner, J.C. and Reynolds, K.J. (2010) The Story of Social Identity. In: Postmes, T. and Branscombe, N., Eds., Rediscovering Social Identity: Core Sources, Psychology Press, New York, 13-32.

[24] Cohen, T., Montoya, R. and Insko, C. (2006) Group Morality and Intergroup Relations: Cross-Cultural and Experimental Evidence. Personality and Social Psychology Bulletin, 32, 1559-1572. https://doi.org/10.1177/0146167206291673

[25] Hamlin, J.K., Mahajan, N. and Wynn, K. (2013) Not like Me = Bad Infants Prefer Those Who Harm Dissimilar Others. Psychological Science, 24, 589-594. https://doi.org/10.1177/0956797612457785 
[26] Scott, F. and Baron-Cohen, S. (1996) Imagining Real and Unreal Objects: An Investigation of Imagination in Autism. Journal of Cognitive Neuroscience, 8, 400-411.

[27] Angus, D., et al. (2015) Limitations in Social Anticipation Are Independent of Imaginative and Theory of Mind Abilities in Children with Autism But Not in Typically Developing Children. Autism, 19, 604-612. https://doi.org/10.1177/1362361314537911

[28] Chan, P., et al. (2016) Theory of Mind Deficit Is Associated with Pretend Play Performance, But Not Playfulness, in Children with Autism Spectrum Disorder. Hong Kong Journal of Occupational Therapy, 28, 43-52. https://doi.org/10.1016/j.hkjot.2016.09.002

[29] Kapogiannis, D., et al. (2009) Cognitive and Neural Foundations of Religious Belief. Proceedings of the National Academy of Sciences, 106, 4876-4881. https://doi.org/10.1073/pnas.0811717106

[30] Calarge, C., Andreasen, N.C. and O'Leary, D.S. (2003) Visualizing How One Brain Understands Another: A PET Study of Theory of Mind. American Journal of Psychiatry, 160, 1954-1964. https://doi.org/10.1176/appi.ajp.160.11.1954

[31] Westen, D. (2008) The Political Brain: The Role of Emotion in Deciding the Fate of the Nation. Public Affairs, New York.

[32] Bell, D. (2015) The China Model: Political Meritocracy and the Limits of Democracy. Princeton University Press, Princeton. https://doi.org/10.1515/9781400865505

[33] Chung, D. (2017) Human Cultural Evolution: Postmodernity as Rational Global Diversity. Open Journal of Social Sciences, 5, 304-337.

[34] Mearsheimer, J. (2001) The Tragedy of Great Power Politics. W.W. Norton \& Company, New York.

[35] Lyotard, J. (1984) The Postmodern Condition: A Report on Knowledge. Manchester University Press, Manchester.

[36] Bremmer, I. (2009) State Capitalism Comes of Age: The End of the Free Market? Foreign Affairs, 88-83, 40-55. 